\title{
ICT Literacy Skill and Electronic Resources Utilization Among Lecturers in the Faculty of Education, Oou, Nigeria
}

\author{
OGUNSANYA, A. O. PhD \\ Department of Arts and Social Science Education, Olabisi Onabanjo University, Nigeria \\ BURAIMO, Olayinka* \\ University Library, Olabisi Onabanjo University, Nigeria
}

\begin{abstract}
This study examined ICT literacy skills and electronic resources utilization among lecturers in the Faculty of Education, Olabisi Onabanjo University, Nigeria. The study adopted survey research design where 56 academic staff been all academic staff in the Faculty of Education were purposively selected to participate in the study. In all, 49 were retrieved valid which accounted for $87.5 \%$ rate of returned. The questionnaire termed" Information Literacy skill Scale" (ILSS) Electronic resources utilization scale" (ERUS) and reason for using electronic resources scale (RUES) instrument were validated by five (5) expert in the Faculty of Education and three (3) other lecturers outside the faculty. The reliability of the instrument was determined by using Cronbach's' coefficient alpha $(\alpha)$ values with the following $\alpha$ scores: ICT literacy skill $=0.81$, electronic resources utilization $=$ 0.87 , Purpose of using electronic resources $=0.76$. Data gathered were analyzed using descriptive statistics (simple percentage, mean \& standard deviation) and regression analysis . Findings from the study revealed a high level of ICT literacy skill and a high level of electronic resources utilization. The top notable purposes of electronic resources utilization as indicated by the sampled audience were to update knowledge/research purposes, to share knowledge, for publication of journal/ articles, for writing of thesis /dissertation among many others. Besides, the findings also revealed a significant relative influence of ICT literacy skill on electronic resources utilization. It is hereby recommended that special notice board through the library should be created across faculties in the university on lists of electronic resources and how to assess them. Not only that, the university management should made fund necessarily available either through TETFUND intervention or other means for subscription of more scholarly electronic information resources and databases in order to build a strong collection of e-resources in the library for the usage among its clientele including the academic staffs.

Keywords: ICT Literacy Skill, Electronic Resources Utilization, Lecturers, OOU, Nigeria.

DOI: $10.7176 /$ JIEA/11-1-04
\end{abstract}

Publication date: January $31^{\text {st }} 2021$

Background to the study

The roles and responsibilities of academic staffs in any tertiary institutions in meeting with the stipulated aims and objectives of its establishment cannot be overestimated. According to National policy on education(FGN,2004) academic staffs are responsible for teaching, research, dissemination of existing and new information, pursuit of service to the community and being a store house of knowledge. In addition to the above, Ojeniyi and Adetimirin (2016) revealed that lecturers at all level of education are also expected to impart meaningful knowledge to students, assist the students in their research/reports writing, offer public services to his/her community by public lectures amongst others and in all they also need to published articles in a reputable journal, attend conferences/delivering of papers, writing of books etc which he/she will be evaluated upon for productivity as well as promotion in his or her chosen career. Since we are in $21^{\text {st }}$ century, which is driven by information and communication technologies, it is therefore mandatory for academic staffs to be proficient in ICT literacy skill in order to utilize electronic resources needed for teaching, researching and for disseminating of existing and new information amongst others and also meet with the stipulated aim and objective of university education as stated above and above all, they also need to compete favourably with other academic staffs in more advance economy.

This is why Iyanda, Okpele and Akintude (2016) noted that Information Communication Technology (ICT) has become part of everyday life that makes human lives more comfortable and easy. In their own view, Iyanda et al (2016) describe ICT as the convergence of computers and communication technologies which makes processing, storage, and retrieval faster, instant and effective. Kolawale (2008) on the other hand refers to ICT as the technologies that help in recording, storing, processing, retrieving, transferring, and disseminating recorded information. Information and Communication Technology is therefore an umbrella term that includes any communication device for teaching and learning. Such device could be computer system, communication device, telecommunication, telephone, satellites, telex, facsimile, internet, email, fax, video text and document delivery, electronic copiers, radio, television, etc. Hence, with the introduction of information and communication technology in Nigerian higher institutions, information dissemination among the academic communities has been tremendously enhanced. 
When talking about ICT literacy skill, it is much more than just having knowledge about computer or what is all about. According to Iyanda et al (2016), ICT literacy refers to the ability to use digital technology communication tools and networks appropriately to solve information problems. ICT literacy thus includes the ability to use technology as a tool for researching, organizing, evaluating and communicating information, and the possession of a fundamental understanding of the ethical and legal issues surrounding access and the use of information. According to Anyim (2018), ICT literacy skill is the ability to use digital technology, communication tools, and/or networks to define access, manage, integrate, evaluate, create, and communicate information ethically and legally in order to function in a knowledge society.

ICT literacy skill in general term is the ability to use digital technologies, communication tools, and networks appropriately to solve information problems in order to fit in into the society driven by information and communication technology (Anyim, 2008). According to Anyin (2008) having the required ICT literacy skill indicated that academic staffs can find information on the web, online databases, CD-ROMS and other digital sources in order to utilize available electronic resources around them. Claro, Priess, San, Jara, Hinostroza, Valenzuela, Cortes,\& Nussbaum, (2012) also refers literacy in Information and Communication Technology (ICT) as the capacity to solve problems of information, communication and knowledge in digital environments. They further stressed that ICT literacy requires both functional skills and higher-order cognitive skills.

On the other hand, Mawere and Sai (2018) define electronic resources or sometimes refers to as electronic information resources as the collections of information in electronic or digital format that are accessed on an electronic device, such as a mobile phone, computer, etc. In the Work of Akuffo and Budu (2019), electronic resources is also refers to as electronic information storage systems accessed via electronic systems and computer networks. Electronic resources or electronic information resources is also refers to as any materials or resources that need access either remotely (via the Internet using a personal computer or mainframe or handheld mobile device) or locally (IFLA; 2012). To Sukula (2010), electronic resources or electronic information resources can also be define as any resources that can be accessed through the internet or the web.

According to Okiki and Asiru (2011), electronic resources also refers to information stored and transmitted in digital, electronic or computerized formats such as diskettes, CD-ROM databases, DVDs, online public access catalogues (OPAC), bibliographic and full-text databases, electronic journals, scholarly databases, information gateways, e-books, the Internet and electronic mails. Similarly, Odunewu and Aluko-Arowolo (2018) refers to electronic resources as computer based database of books, journals, dictionaries, encyclopedias and other information resources. According to them, for any users (students, staffs etc) to be able to utilize electronic resources effectively and efficiently, they must be skillful in information literacy and have a high level computer use competence/ICT.

Studied have been carried out on perceived level of ICT literacy skill, electronic resources utilization, influence of information literacy skill on electronic resources utilization as well as purpose of electronic resources utilization. For instance, Archibong, Ogbiji and Anijaobi-Idem (2010) investigated the ICT competence and challenges to ICT usage among academic staff in River state Nigeria. It was revealed that majority (53.3\%) rated their ICT competence as low. Moreso, Iyanda, Opele \& Akintunde (2016) examined ICT literacy skills and internet usage patterns of library users in Osun State College of Education Ila-Orangun, Nigeria. It was recorded that the library users including lecturers possessed a moderate level of ICT competency/skill. Moreso, findings also indicate a significant relationship between ICT literacy skill of lecturers and other users and internet usage

In a study on Lecturers and students use of ICTs in Nigerian university education as a panacea for national development as conducted by Nwankwoala (2015) revealed that ICT usage contributed to national development. Moreso, Ivwighreghweta and Oyeniran (2013) examined the level of Usage and Awareness of E-resources by lecturers in two Federal University, Delta State Nigeria and found out that the level of usage of electronic resources among lecturers is high. Yebowaah and Pockey (2017) in their study on Awareness and Use of Electronic Resources among academic staff in Wa campus, Ghana find out that the level of awareness of electronic resources is high but the level of electronic resources utilization is low.

Ojeniyi and Adetimirin (2016) investigated the influence of Information and Communication Technology (ICT) literacy skills on electronic information resources (EIR) use among lecturers of two private universities in Oyo State, Nigeria. The findings among others revealed that lecturers in the two private university had a high level of ICT literacy skills. It was also gathered that there was a positive significant relationship between ICT literacy skills and e-resources use among lecturers. In addition, Ekong and Ekong (2018) investigated the influence of information literacy skills on the use of e-library resources in tertiary institutions in Akwa Ibom State. The study reveal that the level of e-library resources utilisation is significantly dependent on knowledge and information literacy skills possessed. In the same vein, Ndagi and Madu (2018) examined the effect of information literacy skills on use of electronic library resources by lecturers in universities in North Central Nigeria. It was also revealed that there exists strong positive correlation between information literacy skills and utilization of electronic resources.

Consequently, academic staff in Nigerian university/academic institutions uses electronic resources for 
different purposes. For example, Ivwighreghweta and Oyeniran (2013) discovered that the main purpose of using electronic resources by lecturers is for research work and the channel of access of these electronic information resources is through the search engines and the University e-library portal/websites. In the same way, Okiki (2012) also observed in his study that research activities, paper writing for publication, and preparation for teaching and learning were among the reason why academic staff make use of electronic resources. In a study conducted by Aregbesola and Oguntayo (2014) in a private university in Nigeria, it was revealed that faculty members also make use electronic resources for academic and other purposes.

\section{Statement of the Problem}

Aside from possessing ICT literacy skill experiences towards teaching and learning process in the classroom environment, academic staff in any academic institution all over the world requires some level of e-resources utilization in order to progress in his/her chosen career. In order to utilize electronic resources effectively and efficiently, academic Staff need to posses some level of ICT literacy skills in order to be 21 st century compliance which is driven by information and communication technology. Despite this huge importance and coupled with the roles of ICT in every other aspect of life such as communication, entertainment, development, and also in teaching and learning process as mentioned earlier, it is sadden to note that many lecturers (academic staffs) in some Nigerian university seems to jettison the role of ICT skills thereby do not optimally utilize e-resources either in publications and/or during teaching and learning process because they lack the require knowledge, literacy and skill in ICT. In support of the above assertions, findings by Archibong, Ogbiji and Anijaobi-Idem (2010) stressed that ICT literacy among academic staff has been viewed as a prerequisite in adoption, integration of ICT and eresources utilization in the school system. They further concluded that the level of ICT literacy skill posses among lecturers in Nigeria towards teaching and learning situation is still very minimal and are such, limiting them towards utilization of e-resources. Similarly, Ndagi and Madu(2018) stressed that many lecturers in universities in Nigeria have been encountering problems in a bid to access and utilize e-resources to support their functions due to their low level of information literacy skills cum ICT literacy skills.

Thus, for lecturers in the Faculty of Education, Olabisi Onabanjo University, Nigeria to provide the desired information that will match the requirements of the 21 st century to their students, and for them also to effectively utilize electronic resources both for self development and teaching and learning process, they need to possessed optimal level of ICT literacy skill that will enhance their e-resources utilization. It is based on the above that this study seeks to examine the ICT literacy skills and electronic resources utilization among lecturers in the Faculty of Education, Olabisi Onabanjo University, Ogun State, Nigeria. Specifically, this study seeks to:

1. Assess the perceived level of ICT literacy skills possessed by lecturers in the Faculty of Education, OOU, Nigeria

2. Find out the perceived level of electronic resources utilization by lecturers in the Faculty of Education, OOU, Nigeria

3. Investigate the purpose by which lecturers in the Faculty of Education, OOU, Nigeria make use of electronic resources

4. Investigate the influence of ICT literacy skill on electronic resources utilization among lecturers in the Faculty of Education, OOU, Nigeria

\section{Research Questions}

1. What is the perceived level of ICT literacy skill possessed by lecturers in the Faculty of Education, OOU, Nigeria?

2. What is the perceived level of electronic resources utilization by lecturers in the Faculty of Education, OOU, Nigeria?

3. Why do the lecturers in the Faculty of Education, OOU, Nigeria make use electronic resources?

\section{Hypothesis}

1. There is no significant influence of ICT literacy skill on electronic resources utilization among lecturers in the Faculty of Education, OOU, Nigeria

\section{Theoretical Review}

In literature, theories abound that are related to technology, Internet, ICT Literacy, E-resources utilization and the application and use of information and communication technology in general. Among theories considered relevant in this study are: Use and Gratification Theory, Technology Acceptance Model, amongst other. For the purpose of this study, Technology Acceptance Model is considered suitable for the study.

Technology Acceptance Model.

Technology acceptance model was propounded by Davis' (1989). According to this theory, factors that affect 
individual's action and purpose for using and adopting the use of Information and communication technology. According to the model, there are two critical factors that determining the use of electronic resources which are; perceived usefulness (PU) and perceived ease of use (PEOU) (Thistoll 2011). In addition to two critical factors, Venkatesh, Morris, Davis and Davis (2003) have also explained that attitude of users towards using technology (ATUT) irrespective of been old or newly invented also influenced the use of electronic resources and ICT in general. According to Davis (1989) and Kalusopa (2011), both the perceived usefulness and perceived ease of use has a lot to do with the attitude of individuals toward the use of technology and electronic resources likewise the internet.

Perceived usefulness therefore is the extent to which patron anticipates benefits he or she will be derived when using technology or electronic resources and perceived ease of use is the extent to which patron or users can go in the use of electronic resources or technology in general as a result of the level of skill and competence possessed in ICT without any obstacle or hindrance (Davis 1989). Attitude on the other hand according to Venkatesh et al.(2003) is regarded as one's general behaviour towards the use of a technology which is dependent on the level, skill and competence possessed in ICT.

From the above therefore, the technology acceptance model was relevant to investigate the link between lecturers ICT competency skills and their level of electronic resources utilization. The model specifically will helped to determine lecturers level of ICT literacy skill, how they accessed and used e-resources, the purposes of using e-resources and the level of e-resources utilization.

\section{Methodology}

The study adopted the descriptive survey design. The population of this study consisted of all the 56 academic staff in the five existing Department in the Faculty of Education, Olabisi Onabanjo University, Nigeria. Because the entire population understudy is not too large to cover, total enumeration technique was adopted to the extent that all the lectures in the existing five Department in the Faculty of Education, Olabisi Onabanjo University, Nigeria constitute the sample for the study as stated in table 1 below:

\section{Table 1: Sample Size for the Study}

\begin{tabular}{|l|l|l|}
\hline S/N & Department & No of Academic Staffs \\
\hline 1 & Arts and Social Science Education & 12 \\
\hline 2 & Educational Foundation and Counseling & 12 \\
\hline 3 & Human Kinetics and Health Education & 9 \\
\hline 4 & Science and Technology Education & 13 \\
\hline 5 & Educational Management and Business Education & 10 \\
\hline & Total & 56 \\
\hline
\end{tabular}

In this study, a structured questionnaire was adopted for data collection which was divided into four (04) sections. The first section was based on demographic information like gender, age, and status and work experience. The second section was termed "ICT Literacy Skills Scale" (ILSS) which contain a 15-items statement that was used to measure the perceived ICT literacy skill of lecturers. The third section was tagged "Electronic Resources Utilization Scale" (ERUS) which contained 9 items statement which was used to measure the perceived electronic resources utilization of lecturers. The fourth section was tagged "Purpose of Electronic Resources Utilization scale" (PERUS) which contained 9 items statement which was used to measure the reason for using electronic resources. All the items were structured on a five point Likert scale rating ranging from Very High, High, Moderate, Low, Very low for perceived ICT literacy skill and electronic resources utilization respectively. While, the purpose of electronic resources was structured on the five rating scale: Strongly Agree, Agree, Undecided, Disagree and Strongly Disagree. The self designed structured questionnaires were given to five (05) lecturers from the Faculty of Education and three (03) other experts in other faculties for criticism and validation, after which corrections were made. Thereafter, the instrument were subjected to reliability test using 10 administered questionnaire for test-re-test from lecturers in other Faculties which gave a cronbach alpha reliability index of $0.81,0.87$, and 0.76 for ICT literacy skill, electronic resources utilization and purpose of using electronic resources respectively.

Data analyses were carried out using both the descriptive statistics (percentages, Means and Standard Deviation) and inferential statistics (Regression) at 0.05 level of significant. 
Result and Discussion

Table 1: Demographic Characteristics of Respondents

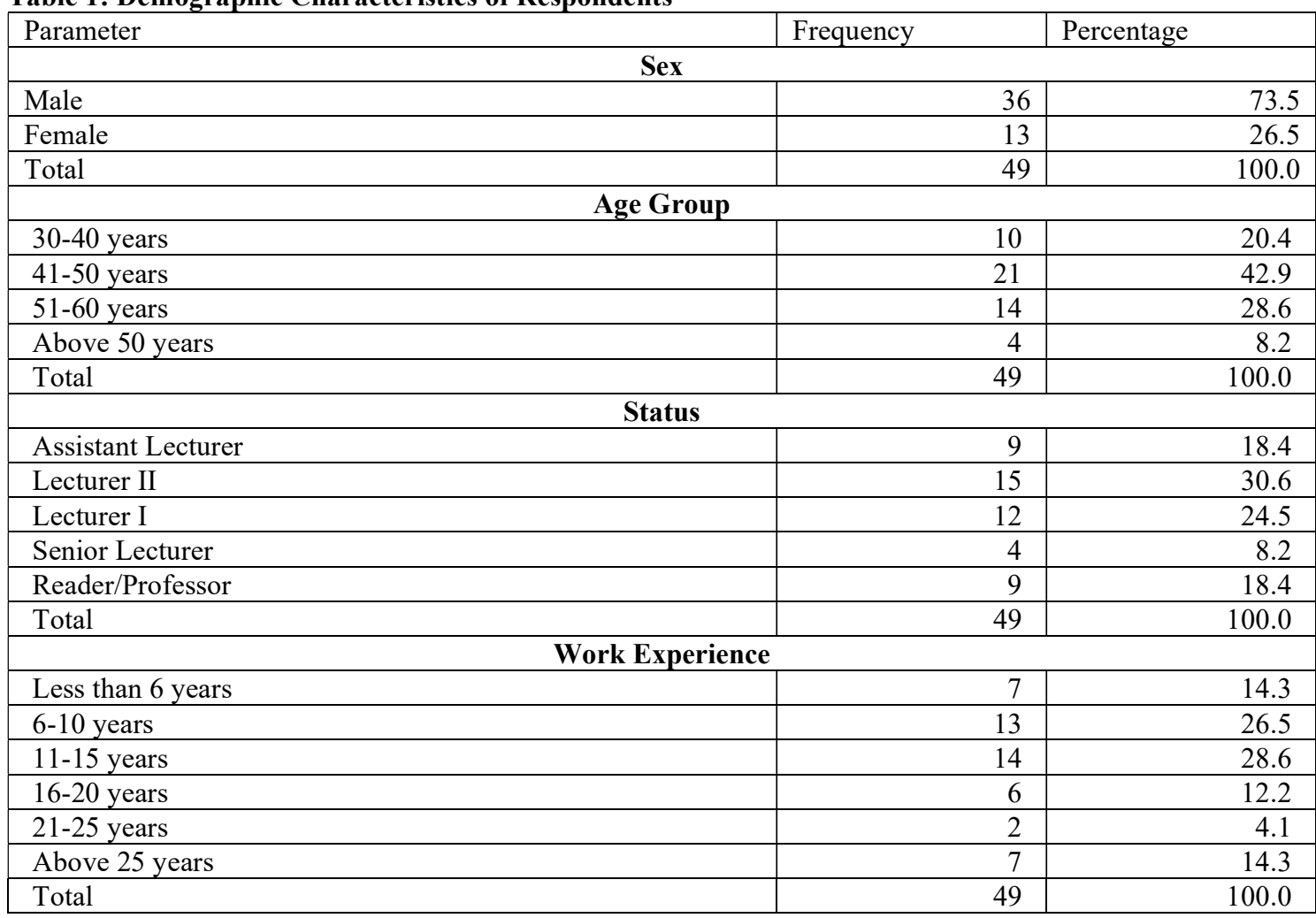

\section{Source: Field Data, 2020}

Result in table 2 revealed the demographic distribution of respondents by gender, age group, status and work experience. From the table, it is obvious that the male respondents were in the majority while the age group 41-60 years dominated the study group. In addition, it is also obvious that Lecturer II and Lecturer I were in the majority while work experience of 6-15 years dominated the study group.

\section{Research Questions}

One: What is the perceived level of ICT literacy skill possessed by lecturers in the Faculty of Education, OOU, Nigeria?

Table 2: perceived level of ICT Literacy Skill of Lecturers

\begin{tabular}{|c|c|c|c|c|c|c|c|c|}
\hline $\mathrm{S} / \mathrm{N}$ & $\begin{array}{l}\text { Lecturers perceived Level of } \\
\text { ICT Literacy Skill }\end{array}$ & $\begin{array}{l}\text { Very } \\
\text { High }\end{array}$ & High & Moderate & Low & $\begin{array}{l}\text { Very } \\
\text { Low }\end{array}$ & Mean & STD \\
\hline 1 & Possesses Internet searching skill & $\begin{array}{c}14 \\
(28.6 \%)\end{array}$ & $\begin{array}{c}24 \\
(49.0 \%)\end{array}$ & $\begin{array}{c}9 \\
(18.4 \%)\end{array}$ & $\begin{array}{c}2 \\
(4.1 \%)\end{array}$ & $\begin{array}{c}0 \\
(0.0 \%)\end{array}$ & 4.02 & 0.80 \\
\hline 2 & $\begin{array}{l}\text { Proficiency in sending and } \\
\text { receiving messages via an e-mail }\end{array}$ & $\begin{array}{c}14 \\
(28.6 \%)\end{array}$ & $\begin{array}{c}22 \\
(44.9 \%)\end{array}$ & $\begin{array}{c}13 \\
(26.5 \%)\end{array}$ & $\begin{array}{c}0 \\
(0.0 \%)\end{array}$ & $\begin{array}{c}0 \\
(0.0 \%)\end{array}$ & 4.02 & 0.75 \\
\hline 3 & $\begin{array}{l}\text { Proficiency in booting and } \\
\text { shutting down computer system }\end{array}$ & $\begin{array}{c}14 \\
(28.6 \%)\end{array}$ & $\begin{array}{c}20 \\
(40.8 \%)\end{array}$ & $\begin{array}{c}15 \\
(30.6 \%)\end{array}$ & $\begin{array}{c}0 \\
(0.0 \%)\end{array}$ & $\begin{array}{c}0 \\
(0.0 \%)\end{array}$ & 3.98 & 0.78 \\
\hline 4 & $\begin{array}{l}\text { Proficiency in the use of ICT to } \\
\text { effectively communicate from } \\
\text { one person to another via the } \\
\text { internet }\end{array}$ & $\begin{array}{c}11 \\
(22.4 \%)\end{array}$ & $\begin{array}{c}27 \\
(55.1 \%)\end{array}$ & $\begin{array}{c}9 \\
(18.4 \%)\end{array}$ & $\begin{array}{c}2 \\
(4.1 \%)\end{array}$ & $\begin{array}{c}0 \\
(0.0 \%)\end{array}$ & 3.96 & 0.76 \\
\hline 5 & 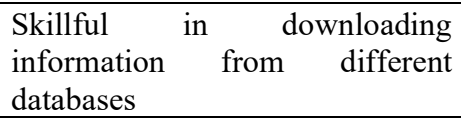 & $\begin{array}{c}12 \\
(24.5 \%)\end{array}$ & $\begin{array}{c}22 \\
(44.9 \%)\end{array}$ & $\begin{array}{c}13 \\
(26.5 \%)\end{array}$ & $\begin{array}{c}2 \\
(4.1 \%)\end{array}$ & $\begin{array}{c}0 \\
(0.0 \%)\end{array}$ & 3.90 & 0.82 \\
\hline 6 & $\begin{array}{l}\text { Skillful in using computer work } \\
\text { without help from the outside }\end{array}$ & $\begin{array}{c}14 \\
(28.6 \%)\end{array}$ & $\begin{array}{c}16 \\
(32.7 \%)\end{array}$ & $\begin{array}{c}19 \\
(38.8 \%)\end{array}$ & $\begin{array}{c}0 \\
0(0 . \%)\end{array}$ & $\begin{array}{c}0 \\
(0.0 \%)\end{array}$ & 3.90 & 0.82 \\
\hline 7 & $\begin{array}{l}\text { Proficiency in the use of google } \\
\text { and other search engine and } \\
\text { storage for future use }\end{array}$ & $\begin{array}{c}9 \\
(18.4 \%)\end{array}$ & $\begin{array}{c}25 \\
(51.0 \%)\end{array}$ & $\begin{array}{c}15 \\
(30.6 \%)\end{array}$ & $\begin{array}{c}0 \\
(0.0 \%)\end{array}$ & $\begin{array}{c}0 \\
(0.0 \%)\end{array}$ & 3.88 & 0.70 \\
\hline
\end{tabular}




\begin{tabular}{|c|c|c|c|c|c|c|c|c|}
\hline $\mathrm{S} / \mathrm{N}$ & $\begin{array}{l}\text { Lecturers perceived Level of } \\
\text { ICT Literacy Skill }\end{array}$ & $\begin{array}{l}\text { Very } \\
\text { High }\end{array}$ & High & Moderate & Low & $\begin{array}{l}\text { Very } \\
\text { Low }\end{array}$ & Mean & STD \\
\hline 8 & $\begin{array}{l}\text { skillful in using computer and } \\
\text { application software }\end{array}$ & $\begin{array}{c}11 \\
(22.4 \%)\end{array}$ & $\begin{array}{c}21 \\
(42.9 \%)\end{array}$ & $\begin{array}{c}17 \\
(34.7 \%)\end{array}$ & $\begin{array}{c}0 \\
(0.0 \%)\end{array}$ & $\begin{array}{c}0 \\
(0.0 \%)\end{array}$ & 3.88 & 0.75 \\
\hline 9 & $\begin{array}{l}\text { Skillful in using flash drive and } \\
\text { other external drive }\end{array}$ & $\begin{array}{c}14 \\
(28.6 \%)\end{array}$ & $\begin{array}{c}16 \\
(32.7 \%)\end{array}$ & $\begin{array}{c}17 \\
(34.7 \%)\end{array}$ & $\begin{array}{c}2 \\
(4.1 \%)\end{array}$ & $\begin{array}{c}0 \\
(0.0 \%)\end{array}$ & 3.86 & 0.89 \\
\hline 10 & $\begin{array}{l}\text { Proficiency in the use of computer } \\
\text { to prepare briefs and class work } \\
\text { for students }\end{array}$ & $\begin{array}{c}14 \\
(28.6 \%)\end{array}$ & $\begin{array}{c}18 \\
(36.7 \%)\end{array}$ & $\begin{array}{c}13 \\
(26.5 \%)\end{array}$ & $\begin{array}{c}4 \\
(8.2 \%)\end{array}$ & $\begin{array}{c}0 \\
(0.0 \%)\end{array}$ & 3.86 & 0.94 \\
\hline 11 & $\begin{array}{l}\text { Proficiency in the use of ICT to } \\
\text { conduct a full length research }\end{array}$ & $\begin{array}{c}14 \\
(28.6 \%) \\
\end{array}$ & $\begin{array}{c}14 \\
(28.6 \%) \\
\end{array}$ & $\begin{array}{c}17 \\
(34.7 \%) \\
\end{array}$ & $\begin{array}{c}4 \\
(8.2 \%) \\
\end{array}$ & $\begin{array}{c}0 \\
(0.0 \%) \\
\end{array}$ & 3.78 & 0.96 \\
\hline 12 & $\begin{array}{l}\text { Proficiency in the use power point } \\
\text { presentation }\end{array}$ & $\begin{array}{c}9 \\
(18.4 \%) \\
\end{array}$ & $\begin{array}{c}17 \\
(34.7 \%) \\
\end{array}$ & $\begin{array}{c}23 \\
(46.9 \%) \\
\end{array}$ & $\begin{array}{c}0 \\
(0.0 \%) \\
\end{array}$ & $\begin{array}{c}0 \\
(0.0 \%)\end{array}$ & 3.71 & 0.76 \\
\hline 13 & $\begin{array}{l}\text { Can Effectively participate in } \\
\text { online forums and social } \\
\text { networks }\end{array}$ & $\begin{array}{c}5 \\
(10.2 \%)\end{array}$ & $\begin{array}{c}25 \\
(51.0 \%)\end{array}$ & $\begin{array}{c}17 \\
(34.7 \%)\end{array}$ & $\begin{array}{l}2 \\
(4.1 \%)\end{array}$ & $\begin{array}{c}0 \\
(0.0 \%)\end{array}$ & 3.67 & 0.72 \\
\hline 14 & $\begin{array}{l}\text { Proficiency in the use of } \\
\text { Microsoft excel and other } \\
\text { spreadsheet application }\end{array}$ & $\begin{array}{c}9 \\
(18.4 \%)\end{array}$ & $\begin{array}{c}19 \\
(38.8 \%)\end{array}$ & $\begin{array}{c}17 \\
(34.7 \%)\end{array}$ & $\begin{array}{c}4 \\
(8.2 \%)\end{array}$ & $\begin{array}{c}0 \\
(0.0 \%)\end{array}$ & 3.67 & 0.88 \\
\hline 15 & $\begin{array}{l}\text { Proficiency in the application of } \\
\text { ICT in analyzing data }\end{array}$ & $\begin{array}{c}7 \\
(14.3 \%) \\
\end{array}$ & $\begin{array}{c}15 \\
(30.6 \%) \\
\end{array}$ & $\begin{array}{c}17 \\
(34.7 \%) \\
\end{array}$ & $\begin{array}{c}10 \\
(20.4 \%) \\
\end{array}$ & $\begin{array}{c}0 \\
(0.0 \%) \\
\end{array}$ & 3.39 & 0.98 \\
\hline & \multicolumn{8}{|c|}{ Criterion Mean $=3.00 ;$ Weighted Mean $=3.83$} \\
\hline
\end{tabular}

\section{Source: Field Data, 2020}

In table 2, academic staff in the Faculty of Education, Olabisi Onabanjo University, Nigeria were asked to indicate the level of ICT literacy skill they possessed on a five-point Likert using 15 constructs. Lecturers ICT literacy skill was ranked highest in internet searching skill as well as in sending and receiving messages via an email $(\bar{x}=4.00,4.00)$ respectively followed by booting and shutting down computer system $(\bar{x}=3.39)$. The least ranked in a descending order were proficiency in the use of Microsoft excel and other spreadsheet application $(\bar{x}$ $=3.67$ ), can effectively participate in online forums and social networks ( $\bar{x}=3.67$ ) and followed by Proficiency in the application of ICT in analyzing data $(\bar{x}=3.39)$. Using the criterion mean $(\bar{x}=3.00)$ against the weighted mean $(\bar{x}=3.83)$ as benchmark to determine lecturers level of ICT literacy skill, One can therefore submitted that academic staff in the Faculty of Education in O.O.U., Nigeria possessed high level of ICT Literacy skills. Findings above corroborate with the work of Ojeniyi and Adetimirin (2016) who reported high level of ICT literacy skill among lecturers in private universities in Oyo State, Nigeria. Findings also correlate with that of Ndagi and Madu (2018) who reported high level of information literacy skills among lecturers. On the other hand, finding negate that of Archibong, Ogbiji a Anijaobi-Idem (2010) who reported low level of ICT competence among lecturers in public university in Cross River State, Nigeria. .

Two : What is the perceived level of electronic resources utilization by lecturers in the Faculty of Education, OOU, Nigeria?

Table 3: Perceived level of electronic resources utilization

\begin{tabular}{|l|l|c|c|c|c|c|c|c|}
\hline S/N & $\begin{array}{l}\text { Perceived level of Electronic } \\
\text { resources utilization }\end{array}$ & $\begin{array}{l}\text { Very } \\
\text { High }\end{array}$ & High & Moderate & Low & $\begin{array}{l}\text { Very } \\
\text { Low }\end{array}$ & Mean & STD \\
\hline 1 & Google & $\begin{array}{c}12 \\
(24.5 \%)\end{array}$ & $\begin{array}{c}15 \\
(30.6 \%)\end{array}$ & $\begin{array}{c}22 \\
(44.9 \%)\end{array}$ & $\begin{array}{c}0 \\
(0.0 \%)\end{array}$ & $\begin{array}{c}0 \\
(0.0 \%)\end{array}$ & 3.80 & 0.82 \\
\hline 2 & Google + & $\begin{array}{c}9 \\
(18.4 \%)\end{array}$ & $\begin{array}{c}16 \\
(32.7 \%)\end{array}$ & $\begin{array}{c}21 \\
(42.9 \%)\end{array}$ & $\begin{array}{c}2 \\
(4.1 \%)\end{array}$ & $\begin{array}{c}1 \\
(2.0 \%)\end{array}$ & 3.61 & 0.91 \\
\hline 3 & CD-ROM Databases & $\begin{array}{c}8 \\
(16.3 \%)\end{array}$ & $\begin{array}{c}14 \\
(28.6 \%)\end{array}$ & $\begin{array}{c}25 \\
(51.0 \%)\end{array}$ & $\begin{array}{c}2 \\
(4.1 \%)\end{array}$ & $\begin{array}{c}0 \\
(0.0 \%)\end{array}$ & 3.57 & 0.82 \\
\hline 4 & Electronic Journals & $\begin{array}{c}8 \\
(16.3 \%)\end{array}$ & $\begin{array}{c}14 \\
(28.6 \%)\end{array}$ & $\begin{array}{c}25 \\
(51.0 \%)\end{array}$ & $\begin{array}{c}2 \\
(4.1 \%)\end{array}$ & $\begin{array}{c}0 \\
(0.0 \%)\end{array}$ & 3.57 & 0.82 \\
\hline 5 & Electronic Thesis & $\begin{array}{c}7 \\
(14.3 \%)\end{array}$ & $\begin{array}{c}17 \\
(34.7 \%)\end{array}$ & $\begin{array}{c}21 \\
(42.9 \%)\end{array}$ & $\begin{array}{c}4 \\
(8.2 \%)\end{array}$ & $\begin{array}{c}0 \\
(0.0 \%)\end{array}$ & 3.55 & 0.84 \\
\hline 6 & Electronic Databases & $\begin{array}{c}8 \\
(16.3 \%)\end{array}$ & $\begin{array}{c}14 \\
(28.6 \%)\end{array}$ & $\begin{array}{c}23 \\
(46.9 \%)\end{array}$ & $\begin{array}{c}4 \\
(8.2 \%)\end{array}$ & $\begin{array}{c}0 \\
(0.0 \%)\end{array}$ & 3.53 & 0.87 \\
\hline 7 & Electronic Dissertation & $\begin{array}{c}8 \\
(16.3 \%)\end{array}$ & $\begin{array}{c}14 \\
(28.6 \%)\end{array}$ & $\begin{array}{c}23 \\
(46.9 \%)\end{array}$ & $\begin{array}{c}4 \\
(8.2 \%)\end{array}$ & $\begin{array}{c}0 \\
(0.0 \%)\end{array}$ & 3.53 & 0.87 \\
\hline
\end{tabular}




\begin{tabular}{|l|l|l|l|c|c|c|c|c|}
\hline S/N & $\begin{array}{l}\text { Perceived level of Electronic } \\
\text { resources utilization }\end{array}$ & $\begin{array}{l}\text { Very } \\
\text { High }\end{array}$ & High & Moderate & Low & $\begin{array}{l}\text { Very } \\
\text { Low }\end{array}$ & Mean & STD \\
\hline 8 & Electronic Books & $\begin{array}{c}4 \\
(8.2 \%)\end{array}$ & $\begin{array}{c}12 \\
(24.5 \%)\end{array}$ & $\begin{array}{c}31 \\
(63.3 \%)\end{array}$ & $\begin{array}{c}2 \\
(4.1 \%)\end{array}$ & $\begin{array}{c}0 \\
(0.0 \%)\end{array}$ & 3.37 & 0.70 \\
\hline 9 & $\begin{array}{l}\text { OOU Library Portal/Institutional } \\
\text { Repository }\end{array}$ & $\begin{array}{c}2 \\
(4.1 \%)\end{array}$ & $\begin{array}{c}12 \\
(24.5 \%)\end{array}$ & $\begin{array}{c}32 \\
(65.3 \%)\end{array}$ & $\begin{array}{c}3 \\
(6.1 \%)\end{array}$ & $\begin{array}{c}0 \\
(0.0 \%)\end{array}$ & 3.27 & 0.64 \\
\hline
\end{tabular}

\section{Source: Field Data, 2020}

Lecturers were asked to indicate their level of electronic resources utilization on a five-point Likert as shown in Table 3. The table shows that lecturers in the faculty of Education, O.O.U., Nigeria, possessed high level of electronic resources utilization. This inferred that the lecturers can effectively utilize electronic resources both for their personal consumption and for teaching and learning process. The submission above, is indicated by the mean values obtained for each of the indicators/construct used in measuring electronic resources utilization which were all significantly higher than the criterion mean $(\bar{x}=3.00)$. For instance, electronic resources utilization is highest in using google $(\bar{x}=3.80)$, followed by google $+(\bar{x}=3.61)$. In addition, electronic resources utilization is lowest in utilization of electronic book $(\bar{x}=3.39)$ followed using OOU Library Portal/Institutional Repository ( $\bar{x}=3.27$ ). The above corroborate with the work of Ivwighreghweta and Oyeniran (2013) who found high level of usage of electronic resources among lecturers. On the other hand, findings above negate that of Yebowaah and Pockey (2017) who earlier reported low level of electronic resources utilization among academic staff. The result of high level of electronic resources possessed by lecturers in the faculty of education, OOU, Nigeria was as a result of the earlier recorded high level of ICT literacy skill which influence their level of utilization of electronic information resources.

Three: Why do the lecturers in the Faculty of Education, OOU, Nigeria make use electronic resources?

Table 4: Reasons for using electronic resources among lecturers

\begin{tabular}{|l|l|c|c|c|c|c|c|c|}
\hline S/N & $\begin{array}{l}\text { Purpose of electronic resources } \\
\text { utilization }\end{array}$ & SA & A & D & SD & Mean & STD \\
\hline 1 & $\begin{array}{l}\text { To Update } \\
\text { knowledge/Research purpose }\end{array}$ & $\begin{array}{c}21 \\
(42 . \%)\end{array}$ & $\begin{array}{c}28 \\
(57.1 \%)\end{array}$ & $\begin{array}{c}0 \\
(0.0 \%)\end{array}$ & $\begin{array}{c}0 \\
(0.0 \%)\end{array}$ & $\begin{array}{c}0 \\
(0.0 \%)\end{array}$ & 3.43 & 0.50 \\
\hline 2 & To share knowledge & $\begin{array}{c}19 \\
(38.8 \%)\end{array}$ & $\begin{array}{c}30 \\
(61.2 \%)\end{array}$ & $\begin{array}{c}0 \\
0(.0 \%)\end{array}$ & $\begin{array}{c}0 \\
(0.0 \%)\end{array}$ & $\begin{array}{c}0 \\
(0.0 \%)\end{array}$ & 3.39 & 0.49 \\
\hline 3 & Publication of Journal Articles & $\begin{array}{c}21 \\
(42.9 \%)\end{array}$ & $\begin{array}{c}26 \\
(53.1 \%)\end{array}$ & $\begin{array}{c}2 \\
(4.1 \%)\end{array}$ & $\begin{array}{c}0 \\
(0.0 \%)\end{array}$ & $\begin{array}{c}0 \\
(0.0 \%)\end{array}$ & 3.39 & 0.57 \\
\hline 4 & Writing of thesis /dissertation & $\begin{array}{c}24 \\
(49.0 \%)\end{array}$ & $\begin{array}{c}21 \\
(42.9 \%)\end{array}$ & $\begin{array}{c}0 \\
(0.0 \%)\end{array}$ & $\begin{array}{c}0 \\
(0.0 \%)\end{array}$ & $\begin{array}{c}4 \\
(8.2 \%)\end{array}$ & 3.24 & 1.09 \\
\hline 5 & $\begin{array}{l}\text { Preparation } \\
\text { conference/seminar/workshop }\end{array}$ & $\begin{array}{c}17 \\
(34.7 \%)\end{array}$ & $\begin{array}{c}30 \\
(61.3 \%)\end{array}$ & $\begin{array}{c}2 \\
(4.1 \%)\end{array}$ & $(. \%)$ & $(. \%)$ & 3.22 & 0.82 \\
\hline 6 & Preparing lectures for teaching & $\begin{array}{c}18 \\
(36.7 \%)\end{array}$ & $\begin{array}{c}27 \\
(55.1 \%)\end{array}$ & $\begin{array}{c}0 \\
(0.0 \%)\end{array}$ & $\begin{array}{c}0 \\
(0.0 \%)\end{array}$ & $\begin{array}{c}4 \\
(8.2 \%)\end{array}$ & 3.12 & 1.05 \\
\hline 7 & Writing of books & $\begin{array}{c}13 \\
(26.5 \%)\end{array}$ & $\begin{array}{c}31 \\
(63.3 \%)\end{array}$ & $\begin{array}{c}0 \\
(0.0 \%)\end{array}$ & $\begin{array}{c}0 \\
(0.0 \%)\end{array}$ & $\begin{array}{c}5 \\
(10.2 \%)\end{array}$ & 2.96 & 1.09 \\
\hline 8 & Recreation/leisure purposes & $\begin{array}{c}12 \\
(24.5 \%)\end{array}$ & $\begin{array}{c}31 \\
(63.3 \%)\end{array}$ & $\begin{array}{c}2 \\
(4.1 \%)\end{array}$ & $\begin{array}{c}0 \\
(0.0 \%)\end{array}$ & $\begin{array}{c}4 \\
(8.2 \%)\end{array}$ & 2.96 & 1.02 \\
\hline 9 & Preparing for examination & $\begin{array}{c}12 \\
(24.5 \%)\end{array}$ & $\begin{array}{c}28 \\
(57.1 \%)\end{array}$ & $\begin{array}{c}3 \\
(6.1 \%)\end{array}$ & $\begin{array}{c}0 \\
(0.0 \%)\end{array}$ & $\begin{array}{c}6 \\
(12.2 \%)\end{array}$ & 2.82 & 1.18 \\
\hline
\end{tabular}

\section{Source: Field Data, 2020}

Table 4. presented the descriptive statistics showing the reason why lecturers in the Faculty of Education, OOU, Nigeria make use of electronic resources. From the above, the most common purposes were to update knowledge/research purposes $($ Mean $=3.43)$, followed by sharing of knowledge $($ Mean $=3.39)$, publication of Journal Articles (Mean =3.39). The least but also an important purposes is in the area of preparing for examination (Mean $=2.82)$. The findings were in accordance with the work of Ivwighreghweta and Oyeniran (2013), who stressed that the main purpose of using electronic resources by lecturers is for research work. Similarly Okiki (2012) also observed research activity, paper writing for publication, and to update their knowledge as one of the purposes of using electronic resources among lecturers. Findings also corroborate with the work of Aregbesola and Oguntayo (2014) who make a submission that academic staff also make use of electronic resources in order to update their knowledge and also for other academic purposes . 
Hypothesis

There is no significant influence of ICT literacy skills on electronic resources utilization among lecturers in the Faculty of Education, OOU, Nigeria

Table 5. Coefficients of the Linear Regression Analysis for the relative influence of ICT Literacy skill on electronic resources utilization

\begin{tabular}{lrrrrr}
\hline Model & \multicolumn{2}{c}{ Unstandardized Coefficients } & Standardized Coefficients & t & Sig. \\
& $\mathrm{B}$ & \multicolumn{2}{c}{ Std. Error } & Beta & \\
\hline (Constant) & 3.377 & 2.532 & & 1.334 & .189 \\
ICK Skill & .495 & .043 & $\mathrm{R}=.857^{\mathrm{a}} ; \mathrm{R}^{2}=.735 ; \mathrm{F}=130.032 ; p<.05$ \\
& & &
\end{tabular}

a. Dependent Variable: Electronic Resources Utilization

Results in Table 5 indicated a significant outcome. This implies that ICT literacy skills significantly influence electronic resources utilization among academic staff in the Faculty of Education, OOU, Nigeria $(\beta=0.495 ; \mathrm{t}=$ $11.403 ; p<.05)$. Hence, the hypothesis of no significant influence of ICT literacy Skill on electronic resources utilization among lecturers in the Faculty of Education, OOU, Nigeria is hereby rejected. In effect, there is a significant influence of ICT literacy Skill on electronic resources utilization among lecturers in the Faculty of Education, OOU, Nigeria. Findings were in line with the work of Ojeniyi and Adetimirin (2016) who stressed that there was a positive significant relationship between ICT literacy skills and electronic resources utilization among lecturers. Findings also corroborate with that of Ekong and Ekong (2018) who found significant relationship between information literacy skills and electronic resources utilization among tertiary Institution Students in Akwa Ibom State. Lastly, findings also corroborated with that of Ndagi and Madu (2018) who revealed that there exists strong positive correlation between information literacy skills and utilization of electronic resources.

\section{Conclusion}

The role of ICT literacy skills in influencing electronic resources utilization cannot be overestimated. In it is therefore concluded that without the required ICT literacy skill, academic staffs in any tertiary institutions in Nigeria and the rest of the world will find it difficult to effectively utilize electronic information resources available anywhere, everywhere and anyhow to complement his teaching effort as well as for his or her personal consumption. Therefore, it is imperative that lecturers without key information and communication technology literacy skills for professional development may find it difficult if not impossible, to cope with the pace of new and emerging technologies in their teaching career.

\section{Recommendations}

Based on the findings of this study, it is thus recommended that:

1. Lecturers in the faculty of education need more training and retraining in the area of application of ICT in data analysis, power point presentation

2. The University library in OOU, Nigeria should re-orientate their lecturers on how to access electronic information resources subscribed to by the University

3. All the lecturers in the faculty of Education should be provided with computer plus Internet access in their respective offices.

4. There is need for training and re-training of lecturers on computer and ICT generally. It is when one is skillful in ICT that he or she will know how to apply it.

5. The e-library unit of Olabisi Onabanjo University should exploit the selective dissemination of information to attract all the academic staff to different forms of information resources and databases available on the library portal. Such as Proquest, Science Direct, Hinhari, OARE, etc

6. Electronic journal update information should be sent to the mails of lecturers in their areas of interest.

7. Special notice board should be created across faculties on list of electronic resources and how to assess them. This should be done via the University library

8. The university management should provide fund through TETFUND and other means for subscription of more scholarly electronic information resources database in order to build a strong collection of e-resources in the library for the usage by students and academic staff.

9. Lecturers should be encouraged to expand their ICT literacy level to a point of turning classroom environment to ICT based.

\section{REFERENCES}

Akuffo, M.N. \& Budu, S. (2019).Use of electronic resources by students in a premier postgraduate theological university in Ghana. South African Journal of Information Management 21(1),a1026. https://doi.org/ 10.4102/sajim.v21i1.1026.

Anyim, W. O.(2018). Assessment of ICT Literacy Skills of Digital Library Users and Staff in Salem University 
Lokoja, Kogi State, Nigeria. Library Philosophy and Practice (e-journal). 1801.https://digitalcommons.unl.edu/libphilprac/1801.1.

Archibong, I. A., Ogbiji, J. E \& Anijaobi-Idem, F. A. (2010). ICT Competence among Academic Staff in Universities in Cross Rivers State, Nigeria. Computer and Information Science, 3(4),109-115.Available online at: http $\backslash$ www.ccsenet.org/cis.

Aregbesola, A. \& Oguntayo, S. (2014). Use of electronic resources by Faculty Members in Landmark University. Computing, Information Systems, Development Informatics \& Allied Research Journal, 5(2),53-59.

Claro, M., Priess, D. D., San Martin, E., Jara, I., Hinostroza, J. E., Valenzuela, S., Cortes, K. \& Nuss-baum, M.(2012). Assessment of 21st century ICT skills in Chile: Test design and results from high school level students. Computers and Education, 59, 1042-1053. doi: 10.1016/j.compedu.2012.04.004.

Davis, F.D. (1989), 'Perceived usefulness, perceived ease of use, and user acceptance of information technology', MIS Quarterly 13(3):319-340. https://doi.org/10.2307/ 249008.

Ekong, U.O., \& Ekong, V. E. (2018). Impact of Information Literacy Skills on the Use of E-Library Resources among Tertiary Institution Students in Akwa Ibom State. Nigerian Journal of Technology, 37(2),423-431. http:// dx.doi.org/10.4314/njt.v37i2.17.

IFLA Acquisition and Collection Development Section (ed.), 2012, Key issues for e-resource collection development: A guide for libraries, viewed 29 February 2020, from http://www.ifla.org/files/assets/acquisition-collection-development/ publications/Electronic-resourceguide.pdf.

Ivwighreghweta , O \& Oyeniran, K. G (2013). Awareness of E-Resources by Lecturers in Two Selected Nigerian Universities, Journal of Library \& Information Science, 3(4),761-775.

Iyanda, D.F., Opele, J.K. \& Akintunde, B.O. (2016). A study of ICT literacy skills and internet usage pattern of library users in Osun State College of Education, Ila-Orangun, Nigeria. Journal of Management and Technology Study Literacy Skills and Internet Maiden Edition, 137-149.

Kalusopa, T. (2011).'Developing an e-records readiness framework for labour organisations in Botswana', PhD thesis, Dept. of Information Science, University of South Africa.

Mawere, T. \& Sai, K. O. S. (2018).An investigation on e-resource utilisation among university students in a developing country: A case of Great Zimbabwe University. South African Journal of Information Management, 20(1), http://dx.doi.org/10.4102/sajim.v20i1.860.

Federal Government of Nigeria (2004). National Policy on Education. NERD Press:Lagos.

Ndagi, S. S., and Madu, E. C. (2018). Effect of Information Literacy Skills on Use Of Electronic Library Resources By Lecturers In Universities In North Central Nigeria. International Journal of Applied Technologies in Library and Information Management, 4 (3),13 -22

Nwankwoala, H. N. L. (2015). An investigation of Lecturers' and students' use of ICTs in Nigerian university education as a panacea for national development. Research on Humanities and Social Sciences, 5(20),167176.

Ojeniyi, A. O \& Adetimirin, A. E. (2016). ICT Literacy Skills and Electronic Information Resources Use By Lecturers In Two Private Universities In Oyo State, Nigeria. Library Philosophy and Practice (ejournal).1443. http://digitalcommons.unl.edu/libphilprac/1443.

Okiki, O. C., \& Asiru, S. M. (2011). Use of Electronic Information Sources by Postgraduate Students in Nigeria: Influencing Factors. Retrieved from http:/unllib.unl.edu/ LPP/okiki-asiru.htm.

Okiki.O.C. (2012). Electronic information resources awareness, attitude and use by academic staff members of University of Lagos, Nigeria. Retrieved $29^{\text {th }}$ February 2020 : from http://digitalcommons.unl.edu/lipphiprac/828.

Rassiya, K. \& Chinnasamy, K. (2014). Information required for e-resources services provided by academic library. International Journal of Interdisciplinary and Multidisciplinary Studies (IJIMS) 1(6),140-146.

Thistoll, A.M., (2011). A grounded theory of preneurial agency in information technology creation', $\mathrm{PhD}$ thesis, School of Information Management, Victoria University of Wellington.

Venkatesh, V., Morris, M.G., Davis, G.B. \& Davis, F.D. (2003). User acceptance of information technology: Toward a unified view', MIS Quarterly 27(3),425-478. https://doi.org/10.2307/30036540.

Yebowaah, A. F. and Plockey, D.D.F. (2017). Awareness and use of electronic resources in university libraries: a case study of university for development studies. Library Philosophy and Practice. 